\title{
PENGARUH BAHAN PENGENYAL KOMERSIAL FOOD GRADE DAN TEPUNG KORO PEDANG PRA GERMINASI TERHADAP PENINGKATAN KUALITAS TIWUL INSTAN TINGGI PROTEIN
}

\author{
Effect of Commercial Food Grade Thickening Agent and Pre-Germination \\ Jack Bean Flour for Improving the Quality of High Protein Instant Tiwul
}

\author{
Najmah Istikaanah ${ }^{1}$, Munasib $^{2}$ dan Friska Citra Agustia ${ }^{2 *}$ \\ ${ }^{1}$ Jurusan Matematika FMIPA Universitas Jenderal Soedirman \\ ${ }^{2}$ Jurusan Ilmu Gizi FIKES Universitas Jenderal Soedirman \\ *furissuka@yahoo.co.id
}

\begin{abstract}
ABSTRAK
Tujuan penelitian adalah membuat tiwul instan tinggi protein dari mocaf yang disubstitusi tepung koro pedang dan diberi bahan pengenyal komersial food grade untuk meningkatkan aspek sensorinya. Penelitian menggunakan Rancangan Acak Kelompok. Faktor yang diteliti yaitu perlakuan germinasi pada koro (G), tanpa pragerminasi (G1) dan dengan pragerminasi (G2); Proporsi mocaf: tepung koro pedang : tapioka (b/b) $(\mathrm{P}), \mathrm{P} 1=$ 75:15:10, $\mathrm{P} 2=70: 20: 10$ dan $\mathrm{P} 3=65: 25: 10$ dan Penambahan bahan pengenyal (b/b; \% terhadap berat tepung) $(\mathrm{K})$, $\mathrm{K} 1=0,5 \%, \mathrm{~K} 2=0,75 \%$ dan $\mathrm{K} 3=1,0 \%$. Variabel yang diteliti adalah sifat fisikokimia (kadar air, abu, nilai formol, kemampuan rehidrasi, untuk perlakuan terbaik diuji kadar protein dan lemak) serta sifat sensori. Data dianalisis dengan Uji F (anova) dan dilanjutkan dengan DMRT (Duncan Multiple Range Test). Berdasarkan uji indeks efektifitas, tiwul instan terbaik ialah G2P3K3 (dengan pragerminasi; proporsi mocaf- tepung koro pedang-tapioka b/b 65:25:10; pengenyal food grade 1\%). Tiwul instan ini mempunyai kadar air 4,39\% bb; protein 7,05\%bk $(6,74 \% \mathrm{bb})$, lemak 6,39 \%bk (6,11\% bb), Abu 0,98\%bk (0,93\%bb) dan karbohidrat (by difference) 85,54 \%bk

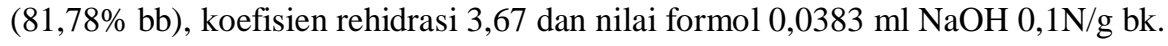

Kata kunci : tiwul instan, mocaf, koro pedang, pragerminasi, bahan pengenyal komersial

\begin{abstract}
The aim of the research was to make high protein instant tiwul from mocaf which was substituted with jack bean flour and given a food grade commercial thickener to improve its sensory aspect. The study used a randomized block design. The factors studied were germination treatment on jack bean $(G)$, without pre germination $(G 1)$ and with pre germination (G2); Proportion of mocaf: jack bean flour : tapioca $(w / w)(F), P 1=75: 15: 10, P 2=70: 20: 10$ and $P 3=65: 25: 10$ and Addition of Commercial food grade thickening agent ( $w / w ; \%$ to flour weight) $(K), K 1=$ $0.5 \%, K 2=0.75 \%$ and $\mathrm{K} 3=1.0 \%$. The variables studied were physicochemical properties (moisture content, ash content, formol value, rehydration ability, for the best treatment, protein and fat content were tested) and sensory properties. Data were analyzed by F test (ANOVA) and continued with DMRT (Duncan Multiple Range Test). Based on the effectiveness index test, the best instant tiwul was G2P3K3 (with pre germination; proportion of mocaf-jack bean flour-tapioca $w / w$ 65:25:10; commercial food grade thickening agent 1\%). This instant tiwul has a water content of $4.39 \% \mathrm{wb}$; protein $7.05 \% \mathrm{db}(6.74 \% \mathrm{wb})$, fat $6.39 \% \mathrm{db}(6.11 \% \mathrm{wb})$, ash $0.98 \% \mathrm{db}(0.93 \% \mathrm{wb})$ and carbohydrates (by difference) $85.54 \% \mathrm{db}(81.78 \% \mathrm{wb}$ ), coefficient rehydration 3,67 and formol value 0,0383 $\mathrm{ml}$ $\mathrm{NaOH} 0,1 \mathrm{~N} / \mathrm{g} b \mathrm{k}$.
\end{abstract}

Keyword : instant tiwul, mocaf, jack bean, pra germinated, commercial thickening agent 


\section{PENDAHULUAN}

Tiwul merupakan salah satu pangan tradisional yang memiliki karakteristik agak kenyal terbuat dari tepung gaplek yaitu ubi kayu yang dikeringkan kemudian dibuat tepung, dan dimakan bersama kelapa parut. Hidayat et al. (2012), menyatakan tiwul instan dibuat dari tepung ubi kayu dengan penambahan sedikit air, gula dan garam yang dicampur sampai homogen kemudian dibentuk granula dan selanjutnya dikukus selama 20 - 30 menit. Tepung ubi kayu sebagai bahan utama tiwul instan dapat dibuat dengan metode fermentasi (Uyoh et al., 2009). Subagyo (2006) menyatakan pengembangan teknologi pengolahan tepung ubi kayu secara fermentasi dalam bentuk mocaf (modified cassava flour). Tiwul berbahan ubi kayu dan mocaf memiliki nilai gizi dan sensori yang rendah sehingga diperlukan formulasi dan modifikasi untuk meningkatkan nilai ekonomi dari tiwul. Agustia et al. (2017 - 2021) telah meneliti pembuatan tiwul instan dengan berbagai penambahan tepung sumber protein nabati untuk meningkatkan kadar proteinnya.

Kacang-kacangan sebagai sumber protein nabati telah banyak digunakan untuk substitusi dan suplementasi dalam pengolahan makanan (Chrestella, 2020; Yuliani et al., 2020; Nurjanati dan Winarsi,
2018; Winarsi, 2018). Kacang koro pedang merupakan salah satu sumber protein nabati yang memiliki kandungan protein sebesar 29,03 \% (Murdiati et al., 2019). Namun, penggunaanya dalam pengolahan makanan memiliki hambatan karena mengandung senyawa antigizi dan senyawa penyebab offflavor (Sridhar dan Seena, 2006; Ahirwar dan Nahar, 2015). Senyawa antigizi tersebut antara lain antitripsin, hemaglutinin, asam fitat dan oligosakarida penyebab flatulensi. Oleh karena itu, perlu dilakukan pragerminasi atau perkecambahan awal untuk meminimalkan senyawa-senyawa yang tidak diinginkan. Secara keseluruhan proses pragerminasi akan menyebabkan perubahan biokimiawi yang meliputi peningkatan kadar gula reduksi, peningkatan konsentrasi asam amino bebas, penurunan kadar lemak serta berkurangnya zat-zat antigizi seperti asam fitat dan oligosakarida penyebab flatulensi seperti raffinosa, stakiosa dan verbakosa. Adanya penurunan kandungan asam fitat berarti ketersediaan mineral dan daya cerna protein akan meningkat (Aguilera et al., 2013; Devi et al., 2015; Benincasa et al., 2019). Pra germinasi yaitu awal perkecambahan yang dilakukan selama 24 jam atau awal tumbuhnya tunas kecambah (2-5mm). 
Tiwul instan supaya kenyal diperbaiki dengan penambahan bahan pengenyal komersial, yaitu bleng food grade yang terdiri atas campuran garam, soda ash light (natrium bikarbonat), sodium tripoliphospat (STPP), pewarna makanan dan air, serta tidak mengandung boraks atau lebih dikenal dengan bahan pengenyal komersial food grade. Bahan pengenyal komersial yang digunakan ini telah lolos uji BPOM dan tersertifikasi dengan POM RI: PM.04.06.952.0612.LL.091. Bahan pengenyal komersial food grade mengandung garam-garam mineral yang berfungsi memberikan rasa asin. Natrium bikarbonat merupakan garam alkali berbentuk serbuk yang larut dalam air dan berfungsi sebagai bahan pengenyal sintetis yang diijinkan (Suryanto et al., 2007). Natrium bikarbonat akan membentuk poripori kecil pada produk tiwul yang akan menyerap air sehingga tiwul menjadi lebih kenyal dan daya rehidrasinya cenderung meningkat (Triana dan Kamila, 2018). Tujuan penggunaan pengenyal ini ialah untuk meningkatkan kekenyalan dan kekompakan, serta memberikan warna kuning alami pada produk tiwul instan yang dihasilkan. Menurut Rukmini dan Naufalin (2015), penambahan bubuk agar sejumlah
$1,25 \%$ dapat meningkatkan kekenyalan tiwul instan 3,13 (kenyal).

Tiwul instan yang dibuat dari mocaf dengan penambahan tepung koro pedang pragerminasi sangat sederhana pembuatannya, murah dan mudah dikonsumsi sehingga akan mengangkat citra tiwul tradisional sebagai pangan lokal potensial menjadi tiwul instan tinggi protein yang memiliki tampilan, cita rasa, aroma, dan sifat tanak yang baik, yang diolah dengan proses relatif sederhana sehingga dapat diterima oleh konsumen. Tujuan dari penelitian ini ialah untuk mengetahui pengaruh perlakuan pragerminasi, proporsi mocaf : tepung koro pedang : tapioka dan untuk mengetahui penambahan bahan pengenyal (b/b; \% terhadap berat tepung) untuk membuat tiwul instan dengan kualitas baik dari aspek kimia dan sensori.

\section{METODE}

\section{Desain, Tempat dan waktu}

Pelaksanaan penelitian selama 6 bulan yaitu bulan Mei hingga Oktober 2020, berlokasi di Laboratorium Teknologi Pengolahan, Jurusan Teknologi Pertanian, Fakultas Pertanian, Universitas Jenderal Soedirman Purwokerto.

$$
\text { Rancangan penelitian yang }
$$
digunakan ialah Rancangan Acak Faktorial. 
Faktor perlakuan terdiri atas; perlakuan germinasi pada koro $(\mathrm{G})$, tanpa pragerminasi (G1) dan dengan pragerminasi (G2); Proporsi mocaf: tepung koro pedang: tapioka $(\mathrm{b} / \mathrm{b})(\mathrm{P}), \quad \mathrm{P} 1=75: 15: 10, \quad \mathrm{P} 2=$ 70:20:10 dan P3 = 65:25:10 dan Penambahan bahan pengenyal (b/b; \% terhadap berat tepung) $(\mathrm{K}), \mathrm{K} 1=0,5 \%, \mathrm{~K} 2$ $=0,75 \%$ dan $\mathrm{K} 3=1,0 \%$. Dari ketiga faktor diperoleh 2 × $3 \times 3=18$ perlakuan, yaitu G1P1K1; G1P1K2; G1P1K3; G1P2K1; G1P2K2; G1P2K3; G1P3K1; G1P3K2; G1P3K3; G2P1K1; G2P1K2; G2P1K3; G2P2K1； G2P2K2； G2P2K3； G2P3K1; G2P3K2; G2P3K3 dan tiap perlakuan diulang sebanyak 2 kali sehingga diperoleh 36 kombinasi perlakuan. Penelitian dilakukan dalam beberapa tahapan yaitu pembuatan mocaf, pembuatan tepung koro pedang, pembuatan tepung koro pedang pragerminasi, pembuatan tiwul instan dengan beberapa kombinasi perlakuan yang diteliti serta pengujian fisikokimia dan sifat sensori tiwul instan.

\section{Alat dan Bahan}

Bahan utama adalah kacang koro pedang dari Bogor, ubi kayu, tapioka, gula, vanili dan bahan pengenyal komersial food grade diperoleh dari Pasar Wage Purwokerto. Bahan kimia yang diperlukan dalam penelitian ini meliputi 1) reagen untuk analisis protein metode Mikro Kjeldahl, antara lain $\mathrm{NaOH} 30 \%, \mathrm{H}_{3} \mathrm{BO}_{3}$, $\mathrm{H}_{2} \mathrm{SO}_{4}$, indikator metal merah-metilen biru, aquades; 2) reagen untuk analisis lemak metode ekstraksi langsung Soxhlet AOAC 2005 yaitu pelarut hexane; 3) Larutan $\mathrm{NaOH}$ dan indikator PP (phenolphthalein) untuk analisis nilai formol.

Alat utama pada pembuatan produk adalah alat masak skala rumah tangga, baskom, dandang, blender, ayakan stainless steel 60 mesh dan 80 mesh, sedangkan alat untuk analisis kandungan gizi adalah oven elektrik, neraca analitik, cawan porselen, pipet mikro, gelas ukur, tanur, desikator, penjepit, soxhlet, labu takar, labu kjeldahl, alat destilasi, labu erlenmeyer, vortex, pipet, kertas saring sentrifugasi, buret dan spektrofotometer.

\section{Tahapan penelitian}

Pembuatan mocaf (Agustia et al., 2018)

Diawali dengan pengupasan ubi kayu kemudian dilakukan pencucian di bawah air mengalir, selanjutnya diiris menggunakan slicer dengan ketebalan $2-3 \mathrm{~cm}$. Proses selanjutnya ialah perendaman dengan larutan ragi tape $2-3 \%$ selama 12 jam, setelah itu dilakukan pencucian dan pengeringan dengan sinar matahari sampai 
J.Gipas, November 2021, Volume 5 Nomor 2

ISSN 2599-0152 eISSN 2599-2465

http://jos.unsoed.ac.id/index.php/jgps

kering patah (menggunakan pengering cabinet suhu $\pm 55-60^{\circ} \mathrm{C}$ selama \pm 24 jam).

Kemudian dilakukan penggilingan dan pengayakan dengan ayakan 60 mesh.

Pembuatan tepung koro pedang (Agustian dan Rukmini., 2017)

Kacang koro pedang dimasukkan ke dalam kain mori atau kain saring lalu diikat menggunakan tali plastik kemudian direbus di dalam larutan $\mathrm{NaOH} 3 \%$ selama $7-8$ menit, selanjutnya dicuci di bawah air mengalir sambil diremas-remas sampai $\mathrm{pH}$ nya netral dan kulit terkelupas. Selanjutnya diiris tipis dan di steam blanching selama 30 menit. Proses selanjutnya di keringkan dalam pengering kabiner pada suhu \pm 55 $60^{\circ} \mathrm{C}$ selama \pm 24 jam atau sampai kering patah, lalu digiling dan diayak menggunakan ayakan 80 mesh.

Pembuatan tepung koro pedang pragerminasi (Agustia dan Rukmini., 2017)

Kacang koro pedang diletakkan dalam wadah lalu disiram air mendidih dengan perbandingan kacang koro pedang : air mendidih sebanyak 1:5 b/v, koro direndam dalam keadaan tertutup selama 8 jam. Selanjutnya Kacang koro pedang diamati hingga mengalami pra-germinasi atau calon batang tumbuh $2-3 \mathrm{~mm}$ dalam waktu tersebut. Proses selanjutnya sama dengan proses pembuatan tepung koro pedang.

Pembuatan tiwul instan

Mocaf, tepung koro pedang dan tapioka dengan persentase sesuai perlakuan penelitian dicampur homogen bersama bahan lain yaitu gula $15 \%$, vanili $0,5 \%$ dan bahan pengenyal komersial food grade sesuai perlakuan $(0,5 \% ; 0,75 \%$ dan $1 \%)$ dan air hangat secukupnya sampai bahan tercampur rata dan terbentuk adonan. Kemudian dilakukan pencetakan awal membentuk granula dan dilanjutkan steam blanching selama 15 menit. Proses selanjutnya granula basah dikeringkan menggunakan pengering kabinet suhu 55 $60{ }^{\circ} \mathrm{C}$ selama \pm 20 jam atau sampai kering patah, ditunggu sampai suhu turun lalu dilakukan pembentukan granula kering sampai ukuran seragam, tiwul instan dikemas rapat dan disimpan sampai waktu analisis dilakukan.

\section{Pengujian-pengujian}

A. Sifat fisikokimia meliputi:

a. Kadar air (metode oven kering AOAC 2005), Kadar abu (metode kering AOAC 2005), Nilai formol (metode titrasi formol AOAC 2005), 
J.Gipas, November 2021, Volume 5 Nomor 2

ISSN 2599-0152 eISSN 2599-2465

http://jos.unsoed.ac.id/index.php/jgps

b. Kemampuan rehidrasi (koefisien rehidrasi) dihitung dengan cara menimbang sampel sebanyak 1 gram (A), kemudian direndam dalam aquades suhu $25{ }^{\circ} \mathrm{C}$ selama 20 menit, lalu ditiriskan 5 menit, dan ditimbang (B), Koefisien rehidrasi dihitung dari B / A (Agustia et al., 2018).

c. Penentuan perlakuan terbaik dilakukan berdasarkan metode indeks efektifitas

d. Kadar protein (metode kjeldahl), Kadar lemak (metode soxhlet) dan karbohidrat by difference.

\section{B. Uji Sensori}

Pengujian sensori meliputi variabel kekenyalan, flavor, rasa khas kacang, warna dan kesukaan menggunakan metode uji skoring dengan range 1 terendah sampai 4 tertinggi. Pengujian dilakukan oleh 25 panelis tidak terlatih terdiri dari laki-laki dan perempuan berusia 18 sampai 23 tahun berbadan sehat serta telah mengikuti mata kuliah uji sensori (Setyaningsih, 2010).

\section{Analisis data}

Data yang diperoleh dianalisis menggunakan analisis ragam atau analisis of variance pada taraf $95 \%$ dan bila terdapat pengaruh nyata $(\mathrm{p}<0,05)$ dilanjutkan dengan uji Duncan's Multiple Range Test (DMRT) pada taraf 5\%. Selanjutnya, data diolah menggunakan Microsoft Excel 2010 dan SPSS 16.0 for Windows.

\section{HASIL DAN PEMBAHASAN}

\section{A. Variabel Kimia dan Fisik}

\section{Kadar Air}

Kadar air tiwul yang dihasilkan dari penggunaan koro pragerminasi $4,61 \%$ lebih tinggi daripada dengan koro tanpa pragerminasi sebesar 3,82\%. Pada proses pragerminasi diawali oleh penyerapan air oleh biji kacang sampai jaringan mempunyai kadar air 40-60\%, kemudian diikuti oleh proses-proses enzimatis disertai meningkatnya respirasi. Selanjutnya diikuti oleh reaksi hidrolisis enzimatis terhadap karbohidrat, protein dan lemak menjadi senyawa-senyawa sederhana yang lebih mudah larut dan mudah dicerna (Sutopo, 2000; Astawan, 2004). Terbentuknya senyawa-senyawa sederhana menyebabkan lebih banyaknya molekul-molekul air yang terikat padanya.

Tiwul dengan proporsi kacang koro yang lebih tinggi memiliki kadar 
air yang lebih tinggi (Tabel 1). Proporsi mocaf-tepung koro-tapioka berpengaruh nyata terhadap kadar air tiwul. Proporsi berat 65:25:10 (P3) menghasilkan tiwul dengan kadar air tertinggi lebih tinggi dari pada tiwul instan dengan proporsi 75:15:10 dan proporsi 70:20:10. Kemungkinan kandungan protein kacang koro yang tinggi memudahkan terjadinya hidrasi protein. Dalam hal ini gugus-gugus hidrofilik protein akan mengikat molekul-molekul air melalui ikatan hydrogen. Menurut Subagio et al. (2003), kacang koro pedang mengandung protein $21,7 \%$, karbohidrat
$70,2 \%$ dan lemak 4,0\%, sedangkan menurut Sudiyono (2010), koro pedang mengandung karbohidrat 60,1\%, protein $30,36 \%$ dan serat $8,3 \%$. Interaksi pengaruh pragerminasi dengan proporsi mocaf-tepung koro-tapioka berpengaruh sangat nyata terhadap kadar air tiwul instan. Pragerminasi koro pedang dan proporsi 65:25:10 (b/b) menghasilkan tiwul dengan kadar air tertinggi $(4,83 \%)$. Koro hasil pragerminasi yang digunakan dalam proporsi tinggi menyebabkan kadar air tiwul yang tinggi pula (Gambar 1).

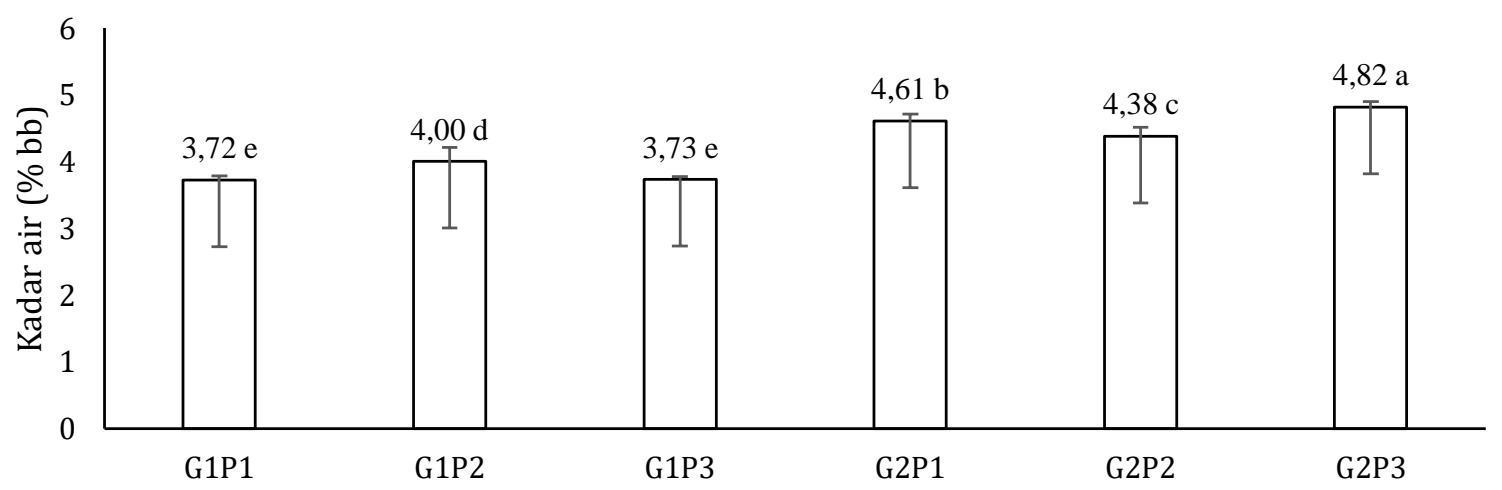

Interaksi antara pengaruh pragerminasi $(\mathrm{G})$ dengan proporsi mocaf-tepung koro-tapioka $(\mathrm{P}: \mathrm{b} / \mathrm{b})$

Gambar 1. Nilai rata-rata kadar air pada berbagai interaksi pengaruh pragerminasi dan proporsi komponen tepung.

Keterangan: G1 = koro tanpa pragerminasi, G2 = koro pragerminasi, proporsi mocaf-tepung koro pedangtapioka (b/b): 75:15:10 (P1), 70:20:10 (P2),65:25:10 (P3).

Interaksi $\mathrm{P}$ (proporsi mocaftepung koro-tapioka) dengan $\mathrm{K}$ (peambahan pengenyal food grade) berpengaruh nyata terhadap kadar air tiwul Tabel 1. Tiwul P3K1 (proporsi 65:25:10 dengan pengenyal food grade $0,5 \%$ memiliki kadar air tetinggi $(4,74 \%)$, sedangkan yang terendah tiwul 
P2K1 (proporsi 70:20:10; pengenyal 0,5\%). Proporsi kacang koro sebagai komponen tepung sangat menentukan tingginya kadar air tiwul. Proporsi koro yang lebih tinggi pada penambahan pengenyal pada persentase sama menyebabkan kadar air tiwul lebih tinggi juga.

Tabel 1. Kadar Fisikokimia Tiwul Instan

\begin{tabular}{|c|c|c|c|c|}
\hline Tiwul instan & Kadar Air (\%bb) & Kadar Abu (\%bk) & Koef Rehidrasi & $\begin{array}{c}\text { Nilai Formol } \\
\mathrm{ml} \mathrm{NaOH} 0,1 \mathrm{~N} / \mathrm{g} \text { bk }\end{array}$ \\
\hline G1P1 & $3,72 \mathrm{e}$ & $1,04 \mathrm{~b}$ & 4,11 & 0,0294 \\
\hline G1P2 & $3,99 \mathrm{~d}$ & $1,03 \mathrm{~b}$ & 3,97 & 0,0284 \\
\hline G1P3 & $3,73 \mathrm{e}$ & $1,13 \mathrm{a}$ & 3,87 & 0,0283 \\
\hline G2P1 & $4,61 \mathrm{~b}$ & $1,01 \mathrm{~b}$ & 3,61 & 0,0483 \\
\hline $\mathrm{G} 2 \mathrm{P} 2$ & $4,38 \mathrm{c}$ & $0,98 \mathrm{~b}$ & 3,82 & 0,0465 \\
\hline $\mathrm{G} 2 \mathrm{P} 3$ & $4,83 \mathrm{a}$ & $0,99 \mathrm{~b}$ & 3,35 & 0,0490 \\
\hline G1K1 & 3,84 & $0,92 \mathrm{~d}$ & $3,78 \mathrm{~b}$ & 0,0271 \\
\hline G1K2 & 3,82 & $1,09 \mathrm{~b}$ & $4,33 \mathrm{a}$ & 0,0335 \\
\hline G1K3 & 3,79 & $1,19 \mathrm{a}$ & $3,84 \mathrm{ab}$ & 0,0254 \\
\hline $\mathrm{G} 2 \mathrm{~K} 1$ & 4,61 & $0,98 \mathrm{c}$ & $3,49 \mathrm{~b}$ & 0,0565 \\
\hline $\mathrm{G} 2 \mathrm{~K} 2$ & 4,63 & $1,01 \mathrm{c}$ & $3,39 \mathrm{~b}$ & 0,0483 \\
\hline $\mathrm{G} 2 \mathrm{~K} 3$ & 4,58 & $0,99 \mathrm{c}$ & $3,89 \mathrm{ab}$ & 0,0390 \\
\hline P1K1 & $4,03 \mathrm{~cd}$ & $0,97 \mathrm{de}$ & $3,95 \mathrm{abc}$ & 0,0522 \\
\hline P1K2 & $4,34 \mathrm{~b}$ & $1,02 \mathrm{bcd}$ & $4,16 \mathrm{ab}$ & 0,0374 \\
\hline P1K3 & $4,13 \mathrm{c}$ & $1,08 \mathrm{ab}$ & $3,49 \mathrm{c}$ & 0,0270 \\
\hline $\mathrm{P} 2 \mathrm{~K} 1$ & $3,90 \mathrm{~d}$ & $0,95 \mathrm{de}$ & $3,64 \mathrm{bc}$ & 0,0303 \\
\hline P2K2 & $4,29 \mathrm{~b}$ & 0,99 cde & $3,63 \mathrm{bc}$ & 0,0461 \\
\hline $\mathrm{P} 2 \mathrm{~K} 3$ & $4,36 \mathrm{~b}$ & $1,07 \mathrm{abc}$ & $4,41 \mathrm{a}$ & 0,0357 \\
\hline P3K1 & $4,74 \mathrm{a}$ & $0,92 \mathrm{e}$ & $3,33 \mathrm{c}$ & 0,0430 \\
\hline P3K2 & $4,04 \mathrm{~cd}$ & $1,14 \mathrm{a}$ & $3,80 \mathrm{abc}$ & 0,0391 \\
\hline P3K3 & $4,07 \mathrm{~cd}$ & $1,12 \mathrm{a}$ & $3,69 \mathrm{bc}$ & 0,0339 \\
\hline G1P1K1 & $3,68 \mathrm{ij}$ & $0,95 \mathrm{de}$ & 3,88 & 0,0329 \\
\hline G1P1K2 & $4,03 \mathrm{fg}$ & $1,03 \mathrm{~cd}$ & 4,71 & 0,0330 \\
\hline G1P1K3 & $3,45 \mathrm{j}$ & $1,13 \mathrm{bc}$ & 3,75 & 0,0224 \\
\hline G1P2K2 & $3,97 \mathrm{fgh}$ & $0,97 \mathrm{de}$ & 4,14 & 0,0382 \\
\hline G1P2K3 & $4,18 \mathrm{ef}$ & $1,17 \mathrm{ab}$ & 4,05 & 0,0243 \\
\hline $\mathrm{G} 1 \mathrm{P} 2 \mathrm{~K} 3$ & 4,18 ef & $1,17 \mathrm{ab}$ & 4,05 & 0,0243 \\
\hline G1P3K1 & 3,99 fgh & $0,86 \mathrm{e}$ & 3,75 & 0,0260 \\
\hline G1P3K2 & $3,47 \mathrm{j}$ & $1,27 \mathrm{a}$ & 4,15 & 0,0294 \\
\hline $\mathrm{G} 2 \mathrm{P} 1 \mathrm{~K} 1$ & $4,38 \mathrm{de}$ & $0,99 \mathrm{de}$ & 4,01 & 0,0715 \\
\hline $\mathrm{G} 2 \mathrm{P} 1 \mathrm{~K} 2$ & $4,65 \mathrm{bc}$ & $1,01 \mathrm{~cd}$ & 3,61 & 0,0419 \\
\hline $\mathrm{G} 2 \mathrm{P} 1 \mathrm{~K} 2$ & $4,65 \mathrm{bc}$ & $1,01 \mathrm{~cd}$ & 3,61 & 0,0419 \\
\hline G2P1K3 & $4,81 \mathrm{~b}$ & $1,04 \mathrm{~cd}$ & 3,22 & 0,0316 \\
\hline $\mathrm{G} 2 \mathrm{P} 2 \mathrm{~K} 1$ & $3,96 \mathrm{fgh}$ & $0,97 \mathrm{de}$ & 3,56 & 0,0381 \\
\hline $\mathrm{G} 2 \mathrm{P} 2 \mathrm{~K} 3$ & $4,55 \mathrm{~cd}$ & $0,96 \mathrm{de}$ & 4,78 & 0,0471 \\
\hline $\mathrm{G} 2 \mathrm{P} 3 \mathrm{~K} 1$ & $5,50 \mathrm{a}$ & $0,99 \mathrm{de}$ & 2,91 & 0,0600 \\
\hline G2P3K1 & $5,50 \mathrm{a}$ & $0,99 \mathrm{de}$ & 2,91 & 0,0600 \\
\hline $\mathrm{G} 2 \mathrm{P} 3 \mathrm{~K} 2$ & $4,61 \mathrm{bcd}$ & $1,02 \mathrm{~cd}$ & 3,45 & 0,0488 \\
\hline G2P3K3 & 4,39 cde & $0,98 \mathrm{de}$ & 3,67 & 0,0383 \\
\hline
\end{tabular}


Angka yang diikuti huruf yang sama tidak berbeda nyata (p>0,05: DMRT 5\%).

Keterangan: G1 = koro tanpa pragerminasi, G2 = koro pragerminasi, proporsi mocaf-tepung koro pedangtapioka (b/b): 75:15:10 (P1), 70:20:10 (P2),65:25:10 (P3), bahan pengenyal (b/b; \% terhadap berat tepung) K1 $=0,5 \%, \mathrm{~K} 2=0,75 \%$ dan $\mathrm{K} 3=1,0 \%$

\section{Kadar Abu}

Secara umum tiwul yang dibuat dengan menggunakan kacang koro pragerminasi mempunyai kadar abu relatif rendah pada proporsi tepung koro pedang yang bervariasi. Hal ini kemungkinan besar diakibatkan oleh larutnya sebagian mineral pada proses pragerminasi. Berbeda dengan pragerminasi yang dilakukan terhadap jenis kacang yang lain seperti kacang hijau dan kedelai, pragerminasi kacang koro dilakukan dengan cara merendamnya di dalam air panas. Perendaman kacang koro dalam air suhu ruang tidak dapat menghasilkan koro pragerminasi karena kacang koro keburu busuk. Hal ini diakibatkan oleh kulit kacang koro yang tebal, kurang lebih 10 kali lipat ketebalan kulit kedelai. Dengan penggunaan air panas, air ini lebih mudah berpenetrasi ke dalam kotiledon kacang koro.

Kacang koro pragerminasi menghasilkan tiwul dengan kadar abu relatif lebih rendah dari pada dengan kacang koro tanpa pragerminasi. Tiwul G1K3 (tanpa pragerminasi dengan pengenyal 1,0\%) mempunyai kadar abu tertinggi. Bahan pengenyal mempunyai kandungan mineral tinggi seperti $\mathrm{Ca}$, $\mathrm{Mg}$, Na, K, dan Cl. Penambahan pengenyal yang semakin tinggi pada jenis kacang koro yang sama (pragerminasi/tanpa pragerminasi) menghasilkan tiwul dengan kadar abu cenderung semakin tinggi walaupun dari aspek statistik tidak signifikan.

Tiwul P3K2 (proporsi mocaftepung koro-tapioka 65:25:10 dengan pengenyal $0,75 \%$ ) mempunyai kadar abu tertinggi $(1,14 \%$ bk) tidak berbeda nyata dengan tiwul P3K3 (proporsi 65:25:10; pengenyal 1,0\%) dengan kadar abu 1,12\% bk. Meningkatnya persentase penambahan pengenyal pada proporsi komponen tepung yang sama menyebabkan peningkatan kadar abu tiwul yang dihasilkan.

Hasil uji $F$ juga menunjukan bahwa GxPxK (interaksi pengaruh pragerminasi dengan proporsi komponen-komponen tepung dan dengan penambahan pengenyal) berpengaruh sangat nyata terhadap kadar abu tiwul. Kadar abu tertinggi 
dihasilkan oleh tiwul G1P3K2 (tanpa pragerminasi, proporsi 65:25:10, penambahan pengenyal $0,75 \%$ ) sebesar 1,27\% bk. Adapun kadar abu terendah dihasilkan oleh tiwul G1P3K1 (tanpa pragerminasi, proporsi 65:25:10, pengenyal 0,5\%) dengan kadar abu $0,86 \%$ bk yang tidak berbeda nyata dengan tiwul G1P1K1 (0,95\% bk) dan dengan tiwul G1P2K1 (0,97\% bk). Dari sini diketahui bahwa penambahan pengenyal food grade yang lebih tinggi menghasilkan tiwul dengan kadar abu lebih tinggi.

\section{Nilai Formol}

Nilai formol menunjukan tingkat hidrolisis protein yang disertai dengan peningkatan asam-asam amino bebas, peptida-peptida dan protein yang lebih mudah larut (Surdarmadji et al.,1997). Hasil menunjukkan bahwa perlakuan pragerminasi meningkatkan secara signifikan nilai formol tiwul instan, yang berarti meningkatkan ketersediaan protein pada produk ini. Nilai formol tiwul dengan menggunakan kacang koro pragerminasi lebih tinggi $(0,0479 \mathrm{ml}$ $\mathrm{NaOH} 0,1 \mathrm{~N} / \mathrm{g}$ bk) dari pada yang tanpa pragerminasi $(0,0287 \mathrm{ml} \mathrm{NaOH} 0,1 \mathrm{~N} / \mathrm{g}$ bk). Hal ini diakibatkan oleh pragerminasi yang antara lain menyebabkan terbentuknya senyawasenyawa dengan bobot molekul rendah hasil hidrolisis protein diantaranya asam-asam amino bebas, peptidapeptida dan protein BM rendah.

\section{Koefisien Rehidrasi}

Koefisien rehidrasi suatu produk kering dihitung berdasarkan seberapa banyak produk tersebut kembali menyerap air pada suhu ruang dalam kurun waktu tertentu. Produk dengan porositas tinggi mempunyai banyak rongga sehingga saat rehidrasi akan lebih mudah menyerap air. Koefisien rehidrasi tinggi penting bagi produk pangan instan karena menggambarkan proses rehidrasi yang tinggi. Tingginya daya rehidrasi pada tiwul instan berasal dari senyawa yang mudah mengikat air yang terkandung di dalamnya terutama protein dan pati, serta diakibatkan oleh bubuk agar yang diberikan dalam jumlah relatif tinggi (2\%). Alvarenga $e t$ al. (2011) meneliti penambahan agar pada pembuatan roti bebas gluten dari campuran tepung beras, tepung jagung dan tapioka sebagai matriks untuk meniru sifat gluten.

Hasil uji $\mathrm{F}$ terhadap tiwul instan menunjukan bahwa interaksi GxK 
(pengaruh pragerminasi dan penambahan pengenyal) berpengaruh nyata terhadap koefisien rehidrasi tiwul instan. Pada tiwul yang dibuat menggunakan kacang koro tanpa pragerminasi, peningkatan persentase penambahan pengenyal menyebabkan peningkatan koefisien rehidrasi tiwul, demikian pula tiwul yang menggunakan kacang koro pragerminasi (Gambar 2). pragerminasi (G2) menghasilkan tiwul dengan koefisien rehidrasi yang lebih rendah $(3,59)$ dari pada yang tanpa pragerminasi $(3,99)$. Menurut Rukmini dan Naufalin (2015), koefisien rehidrasi tiwul instan yang disubstitusi tepung lembaga serealia dan konsentrat protein kedelai berkisar $2-4$, sedangkan menurut Nurbani et al. (2008), beras instan yang dibuat dari tepung gaplek tepung ubi jalar 50:50 b/b mempunyai tingkat rehidrasi sekitar 38,13\%.

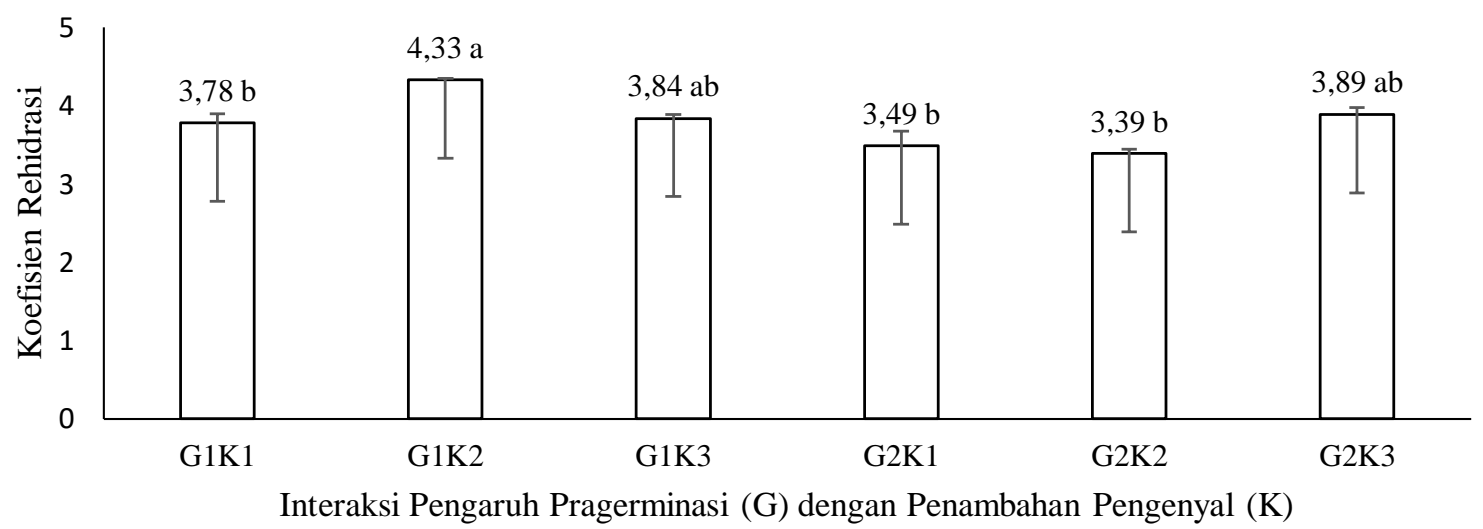

Gambar 2. Nilai rata-rata koefisien rehidrasi pada berbagai interaksi pengaruh pragerminasi dengan penambahan pengenyal.

Keterangan: $\mathrm{G} 1=$ tanpa pragerminasi, $\mathrm{G} 2=$ dengan pragerminasi; $\mathrm{K} 1=0,5 \%, \mathrm{~K} 2=0,75 \%, \mathrm{~K} 3=1,0 \%$.

Hasil uji $\mathrm{F}$ menunjukan bahwa interaksi proporsi komponen-komponen tepung dengan persentase penambahan pengenyal berpengaruh nyata terhadap koefisien rehidrasi tiwul instan. Uji DMRT menunjukan bahwa tiwul P2K3 mempunyai koefisien rehidrasi tertinggi $(4,41), \quad$ sedangkan tiwul P1K3 mempunyai koefisien rehidrasi terendah $(3,49)$ tidak berbeda nyata dengan P3K1 $(3,33)$. Proporsi kacang koro yang tinggi menghasilkan tiwul dengan koefisien rehidrasi relatif lebih tinggi, demikian pula persentase penambahan pengenyal yang lebih tinggi. Kemungkinan interaksi PxK ini 
menghasilkan porositas yang tinggi pada tiwul instal sehingga koefisien rehidrasinya juga tinggi.

\section{B. Variabel Sensori}

\section{Kekenyalan}

Tekstur merupakan faktor
penting dalam penentuan kualitas
produk (Singham et al., 2015). Pada
penelitian ini, tekstur (kekenyalan)
diujikan pada tiwul instan tanak.
Perlakuan pragerminasi kacang koro
(G), proporsi bahan pembuat tiwul (P),
penambahan bahan pengenyal (K), dan
interaksi diantara ketiga perlakuan
tersebut tidak berpengaruh nyata
terhadap kekenyalan tiwul instan tanak.
Diketahui perbedaan yang kecil dari
penambahan pengenyal food grade (K1 $=0,5 \% ; \mathrm{K} 2=0,75 \% ; \mathrm{K} 3=1,0 \%)$ tidak begitu berpengaruh terhadap tingkat kekenyalan tiwul instan tanak sehingga panelis kurang mampu mendeteksi perbedaan kekenyalan dari penambahan pengenyal tersebut. Nilai kekenyalan tiwul instan pada penelitian ini ialah 2,3 - 2,85 (kenyal). Menurut Agustia et al. (2017), tiwul instan yang disubstitusi tepung koro pedang pragerminasi memiliki tekstur dengan kisaran 1,40 2,87 (agak kenyal - kenyal).

\section{Flavor (Cita rasa)}

Persentase penambahan bahan pengenyal food grade berpengaruh sangat nyata terhadap flavor tiwul instan tanak. Nilai flavor tiwul instan dengan penambahan pengenyal $0,5 \%$ adalah pada kisaran cukup enak - enak $(2,49)$ sedangkan yang dengan penambahan pengenyal $0,75 \%$ dan $1,0 \%$ tidak berbeda nyata, keduanya memiliki nilai flavor mendekati enak $(2,60 \quad-\quad 2,75) . \quad$ Kemungkinan penambahan pengenyal $0,75 \%$ dan $1,0 \%$ memberikan flavor yang lebih enak terhadap tiwul instan tanak karena rasa yang agak lebih gurih dan agak lebih asin diakibatkan oleh kandungan garam-garam pada pengenyal tersebut. Bahan pengenyal food grade yang digunakan pada penelitian ini telah lolos uji BPOM dan tersertifikasi dengan POM RI : PM. 04. 06. 952. 06 12. LL. Ogl diantaranya dinyatakan bebas boraks. Pengenyal ini mengandung garam-garam diantaranya natrium bikarbonat.

\section{Rasa Khas Kacang}

Pragerminasi kacang koro akan menurunkan rasa khas kacang (beany flavor) tiwul instan. Interaksi G1P1K1 
(tepung koro tanpa pragerminasi; tepung ubi kayu - tepung koro pedang tapioka 75:15:10; $\mathrm{K} 1=$ pengenyal $0,5 \%)$ menghasilkan tiwul instan tanak dengan nilai khas kacang tertinggi $(3,15)$ yang artinya adalah rasa khas kacang tidak terdeteksi (lebih disukai panelis). Kemungkinan hal ini diakibatkan oleh proporsi tiwul instan yang menggunakan jumlah atau berat tepung koro terendah (15 bagian). Tiwul instan G1P3K2 yang menggunakan proporsi P3 (62:25:10) atau dengan proporsi tepung kacang koro tertinggi (25 bagian) mempunyai rasa khas kacang terendah $(2,55)$ atau rasa khas kacang pada tiwul instan berkisar terdeteksi - tidak terdeteksi (kurang disukai panelis). Rasa khas kacang (beany flavor) umum ditemui pada anggota leguminosa. Rasa ini umumnya diakibatkan oleh aktivitas enzim lipoksigenase pada lemak kacang. Menurut Doss et al. (2011) rasa kacang yang tidak enak disebabkan oleh aktivitas enzim lipoxygenase yang ditemukan secara alami pada bahan (kacang koro pedang).

\section{Warna}

Warna tiwul instan yang dibuat menggunakan tepung koro pragerminasi lebih cerah (kearah putih kekuningan) daripada dengan tepung koro tanpa pragerminasi. Demikian pula tiwul instan yang menggunakan tepung pragerminasi pada persentase penambahan pengenyal yang berbeda $(0,5 \% ; 0,75 \% ; 1,0 \%)$ mempunyai nilai wana lebih tinggi $(3,24-3,61)$ daripada yang dengan tepung koro tanpa pragerminasi pada persentase penambahan pengenyal yang berbeda $(0,5 \% ; 0,75 \% ; 1,0 \%)$ dengan nilai berkisar 2,44 - 3,13. Kemungkinan besar hal tersebut diakibatkan oleh lebih banyaknya zat warna (pigmen) kacang koro yang terlarut pada air perendam panas yang digunakan pada proses pragerminasi kacang koro pedang. Proses awal pragerminasi yang dilakukan terhadap kcang koro pedang adalah dengan menyiram kacang ini dalam air dan kemudian membiarkannya terendam di dalamnya selama 8 jam. Setelah 8 jam kacang koro pedang bergerminasi sekitar $2-5$ $\mathrm{mm}$. Perendaman dalam air suhu ruang tidak mampu membuat kacang koro pedang bergerminasi karena kulitnya yang tebal, sekitar 10 kali lipat ketebalan kulit kedelai. 
J.Gipas, November 2021, Volume 5 Nomor 2

ISSN 2599-0152 eISSN 2599-2465

http://jos.unsoed.ac.id/index.php/jgps

\section{Kesukaan}

Persentase penambahan pengenyal yang lebih tinggi ternyata disukai oleh konsumen. Kenyataan ini sejalan dengan nilai flavor, bahwa pada tiwul instan dengan persentase pengenyal lebih tinggi memiliki nilai flavor yang lebih tinggi pula. Pengenyal food grade yang digunakan memberikan flavor yang lebih enak pada tiwul instan (lebih gurih dan agak lebih asin).

Berdasarkan indeks efektifitas tiwul instan perlakuan terbaik ialah G2P3K3 (dengan pragerminasi; proporsi mocaf- tepung koro pedangtapioka b/b 65:25:10; pengenyal food grade $1 \%$ ). Tiwul instan ini mempunyai kadar air 4,39\% bb; protein $7,05 \%$ bk $(6,74 \%$ bb), lemak 6,39 \%bk $(6,11 \%$ bb), Abu 0,98\%bk (0,93\%bb) dan karbohidrat (by difference) 85,54\%bk $(81,78 \%$ bb), koefisien rehidrasi 3,67 dan nilai formol $0,0383 \mathrm{ml} \mathrm{NaOH}$ $0,1 \mathrm{~N} / \mathrm{g}$ bk.

\section{KESIMPULAN}

Proses pragerminasi kacang koro pedang meningkatkan nilai formol tiwul instan sehingga meningkatkan ketersediaan protein. Proses tersebut menghasilkan warna tiwul instan lebih cerah daripada tiwul instan dengan proses tanpa pragerminasi. Proporsi tepung kacang koro yang lebih tinggi akan meningkatkan kadar protein tiwul instan dan penggunaan bahan pengenyal food grade $1 \%$ terhadap total tepung yang digunakan untuk membuat tiwul instan, menghasilkan tiwul instan yang memiliki nilai flavor lebih tinggi (lebih gurih) dan lebih disukai panelis.

\section{UCAPAN TERIMA KASIH}

Peneliti menyampaikan terima kasih kepada Kementerian Pendidikan dan Kebudayaan yang telah membiayai penelitian ini melalui DANA BLU Unsoed Hibah Penelitian Peningkatan Kompetensi Tahun 2020 dengan SK Ketua LPPM Unsoed Nomor : Kept. 121/UN23.18/PT.01.05/2020. Tanggal 18 Februari 2020.

\section{DAFTAR PUSTAKA}

Aguilera, Y., Díaz, M.F., Jiménez, T., Benítez, V., Herrera, T., Cuadrado, C., Martin-Pedroza, M., dan Martin-Cabrejaz, M.A. (2013). Changes in non-nutritional factors and antioxidant activity during germination of nonconventional legumes. Journal of Agricultural and Food Chemistry, 61(34):81208125. DOI: $10.1021 / \mathrm{jf} 4022652$

Agustia, F.C. dan Rukmini, H.S. 2017. Formulasi tiwul dan beras instan tinggi protein menggunakan tepung ubi kayu-tepung lembaga jagung 
J.Gipas, November 2021, Volume 5 Nomor 2

ISSN 2599-0152 eISSN 2599-2465

http://jos.unsoed.ac.id/index.php/jgps

dengan penambahan konsentrat protein kedelai. Jurnal Gizi dan Pangan Soedirman 1(1):36-54. DOI:

10.20884/1.jgps.2017.1.01.357

Agustia, F.C., Rukmini, H.S., Naufalin, R. 2018. Formulasi Tiwul Instan Tinggi Protein dari Tepung Ubi Kayu yang Disubstitusi Tepung Koro Pedang dan Susu Skim. Jurnal Aplikasi Teknologi Pangan 7(1):15-20. DOI: 10.17728/jatp.2132

Agustia, F.C., Rukmini, H.S., Naufalin, R. dan Ritonga, A.M. 2021. Pendugaan Umur Simpan Tiwul Instan yang Dikemas dalam Aluminium Foil dan Polietilen dengan Metode Akselerasi Berdasarkan Pendekatan Kadar Air Kritis. Jurnal Aplikasi Teknologi Pangan 10(1): 27-32. DOI: 10.17728/jatp.7046

Ahirwar, R., dan Nahar, P. (2015). Development of an aptamer-affinity chromatography for efficient single step purification of Concanavalin A from Canavalia ensiformis. Journal of Chromatography B: Analytical Technologies in the Biomedical and Life Sciences, 997 (105-109). DOI: 10.1016/j.jchromb.2015.06.003

AOAC. 2005. AOAC Official Methods of Analysis. 15th Edn., Association of Official Analytical Chemists, Washington, D.C., pp: 136-138.

Alvarenga, N.B., Lidon, F.C., Belga, E., Motrena, P., Guerreiro, S., Joao, M. 2011. Characterization of Gluten Free Bread Prepared From Maize, Rice And Tapioka Flours Using The Hydrocolloid Seaweed AgarAgar. Recent Research in Science and Technology 3(8):64-68.
Astawan. 2004. Sehat Bersama Aneka Serat Pangan Alami. Tiga Serangkai, Solo.

Benincasa, P., Falcinelli, B., Lutts, S., Stagnari, F., dan Galieni, A. (2019). Sprouted Grains: a Comprehensive Review. Nutrients, 11(421). DOI: 10.3390/nu11020421

Chrestella, O.Y. 2020. Kualitas Kue Pukis Dengan Substitusi Tepung Kacang Merah (Phaseolus vulgaris) Dan Tepung Buah Sukun (Artocarpus communis) Sebagai Sumber Serat. Jurnal Gizi dan Pangan Soedirman 4(2):131-150.

DOI: 10.20884/1.jgipas.2020.4.2.3007

Devi, C.B., Kushwaha, A., dan Kumar, A. (2015). Sprouting Characteristics And Associated Changes In Nutritional Composition Of Cowpea (Vigna unguiculata). J Food Sci Technol, 52(10), 6821-6827. DOI: 10.1007/s13197-015-1832-1.devi

Doss, A., Pugalenthi, M., Vadivel, V.G., Subhashini, G., Anitha. 2011. Effect of processing technique on the nutritional composition and antinutrients content of underutilized food legume Canavalia ensiformis L. DC. International Food Research Journal 18(5): 965-970.

Hidayat, N., Nurika, I., Purwningsih, I., dan Eva, N.W. 2012. A Studi of consumers Acceptance Instant Tiwul and its Financial Analysis. $J$ Agric Food Tech. 2 (12) : 178-183.

Murdiati, A., Wijatniko, B.D., \& Canti, M. (2019). Koro Pedang (Canavalia Ensiformis L. DC) : Budidaya, Kandungan Gizi, Manfaat Bagi Kesehatan dan Produk Olahannya. PT Kanisius, Yogyakarta

Nurbani, K., Hidayat, B., Sufriana. 2008. 
Kajian Optimasi Proses Pengolahan Produk Beras Instan Ubi Jalar (Ipomoea batata L.) varietas Shiroyutaka. J Teknologi Ind hasil Pertanian 13(2) : 85 - 94.

Nurjanati, M. dan Winarsi, H. 2018. Efek Lama Perkecambahan Terhadap Sifat Sensori Dan Kadar Protein Terlarut Susu Kecambah Kacang Merah (Sukarah) Untuk Remaja Obesitas. Jurnal Gizi dan Pangan Soedirman 2(2): 27-42. DOI:

Rukmini, H.S., Naufalin, R. 2015. Formulasi Tiwul Instan Tinggi Protein Melalui Penambahan Lembaga Serealia dan Konsentrat Protein Kedelai. Jurnal Teknologi Industri Pertanian. 25(3): 190-197.

Setyaningsih, D., Apriyantono, A., Sari, M.P. 2010. Analisis Sensori untuk Industri Pangan dan

Agro. IPB Press, Bogor.

Sridhar, K. R., \& Seena, S. (2006). Nutritional and Antinutritional Significance Of Four Unconventional Legumes Of The Genus Canavalia - A comparative Study. Food Chemistry, 99(2), 267-288. DOI: 10.1016/j.foodchem.2005.07.049

Singham, P., Birwal, P., Yadav, B.K. 2015. Importance Of Objective And Subjective Measurement Of Food Quality And Their InterRelationship. Journal Food Process Technology (6):488. DOI:10.4172/2157-7110

Subagio, A., Windrati, W.S., Witono, Y., 2003. Pengaruh Penambahan Isolat Protein Koro Pedang (Canavalia ensiformis L.) Terhadap karakteristik Cake. Jurnal Teknologi dan Industri Pangan,
Universitas Jember.

Subagyo, A. 2006. Pengembangan Tepung Ubi Kayu sebagai Bahan Industri Pangan. Seminar Rusnas Diversifikasi Pangan Pokok Industrialisasi Diversifikasi Pangan Berbasis Potensi Pangan Lokal. Kementrian Ristek dan Seafast Center. IPB, Serpong.

Sudarmaji, S., Bambang, H., dan Suhardi. 1997. Prosedur Analisa Untuk Bahan Makanan Dan Pertanian. Yogyakarta: Liberty

Sudiyono. 2010. Penggunaan $\mathrm{NaH} 2 \mathrm{CO} 3$ untuk Mengurangi Kandungan Asam Sianida (HCN) Koro Bengkuk pada Pembuatan Koro Bengkuk Goreng. Agrika 4(1):4853.

Sutopo, L. 2000. Teknologi Benih. Fakultas Pertanian Unibraw. Rajawali Press, Jakarta.

Triana, L. dan Kamilla, L. 2018. Analisis Kadar Asam Sianida Pada Ubi Kayu Yang Direndam Dalam Larutan $\mathrm{NaHCO} 320 \%$ dengan variasi waktu. Jurnal Laboratorium Katulistiwa 2(2):130-136. DOI: 10.30602/jlk.v1i2.150.

Uyoh, E.A., Ntui, V.O., and Udoma, N.N. 2009. Effect Of Local Cassava Fermentation Methods On Some Physiochemical And Sensory Properties Of Fufu. Pakistan Journal of Nutrition 8(8):11231125

DOI:10.3923/pjn.2009.1123.1125.

Winarsi, H. 2018. Susu Kecambah Kedelai Basah Kaya Protein Lebih Disukai Sebagai Minuman Alternatif Untuk Obesitas. Jurnal Gizi dan Pangan Soedirman 2(1): 32-42. DOI: 10.20884/1.jgps.2018.2.1.896 
Yuliani, Kamsiah, dan Sari, A.P. 2020. Variasi Substitusi Rumput Laut Dan Kacang Merah Pada Produk Flakes Terhadap Mutu Organoleptik Dan Kadar Serat. Jurnal Gizi dan Pangan Soedirman 4(2):164-172. DOI:

10.20884/1.jgipas.2020.4.2.3040. 